\title{
'We will be Written out of History': Feminist Challenges to Carceral Violence and the Activist Archive
}

\author{
BREE CARLTON*
}

EMMA K. RUSSELL*

Carlton, B., and Russell, E.K., 2018. 'We will be Written Out of History': Feminist Challenges to Carceral Violence and the Activist Archive. Oñati Socio-legal Series [online], 8 (2), 267287. Received: 24-01-2017; Accepted: 16-01-2018. Available from: https://doi.org/ 10.35295/osls.iisl/0000-0000-0000-0929

\begin{abstract}
Feminist activism has played an important role in documenting, highlighting and challenging carceral violence against women within and beyond prison walls. Using the campaign against the punitive segregation of women in high-security men's prisons in the 1980s and 1990s in Victoria, Australia, as a case study, we illustrate the value of the activist archive for critical prisons research. The activist archive has the potential to expose continuities in carceral violence, highlight the limitations and potentialities of legal and official oversight processes, and debunk official rhetoric of the prison's reformative and rehabilitative potential. Our discussion demonstrates the extent to which the activist archive can yield a powerful arsenal of accounts, critiques and organising strategies for anti-carceral feminist movements.
\end{abstract}

\section{Key words}

Anti-carceral feminism; abolition; penal reform; women's imprisonment; activist knowledge

\section{Resumen}

El activismo feminista ha desempeñado un importante papel a la hora de documentar, subrayar y cuestionar la violencia carcelaria contra las mujeres, dentro y fuera de las prisiones. Utilizando como estudio de caso la campaña contra la segregación punitiva de mujeres en prisiones de alta seguridad para hombres en los años 80 y 90 en Victoria, Australia, ilustramos el valor del archivo del activismo para la investigación crítica sobre las prisiones. Dicho archivo tiene el potencial de exponer la continuidad de la violencia carcelaria, subrayar las limitaciones y potencialidades de los procesos de revisión legales y oficiales, y desmontar el discurso oficial sobre la capacidad reformatoria y rehabilitadora de la prisión. Nuestra tesis demuestra que el archivo

\footnotetext{
Thank you to the anonymous reviewers and editors of this special issue for comments that greatly improved the article. We extend special thanks to the women and organisations that have dedicated their valuable time in interviews and entrusted precious archival materials for use in this research. Notable thanks go to Amanda George, Billi Clarke, Catherine Gow, Maud Clark, Margi Lardi, Somebody's Daughter Theatre Group and Flat Out.

* Bree Carlton is Senior Lecturer in Criminology in the School of Social Sciences, Monash University, Victoria 3800, Australia. Email address: Bree.Carlton@monash.edu.

* Emma K. Russell is Lecturer in Crime, Justice and Legal Studies in the Department of Social Inquiry, La Trobe University, Victoria 3086, Australia. Email address: E.Russell@latrobe.edu.au
}

\section{(cc) EY-NC-ND}

Oñati International Institute for the Sociology of Law Antigua Universidad s/n - Apdo.28 20560 Oñati - Gipuzkoa - Spain

Tel. (+34) 943783064 
activista puede dotar al movimiento feminista anticarcelario de un rico muestrario de testimonios, críticas y estrategias organizativas.

\section{Palabras clave}

Feminismo anticarcelario; abolición; reforma penal; encarcelamiento de mujeres; conocimiento activista 


\section{Table of contents / Índice}

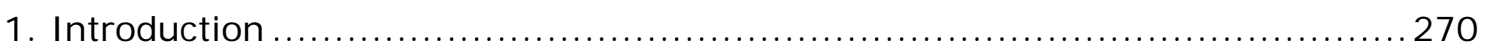

2. The Activist Archive as Anti-Carceral Feminist Praxis .......................... 271

3. Women's Imprisonment and Activism in 1980s Victoria, Australia ................273

4. Resisting and Documenting Carceral Violence from Within ...................... 274

5. Reformist Discourses and Official Denial ...................................... 278

6. The Possibilities of Counter-Narratives and Activist Archives.................... 280

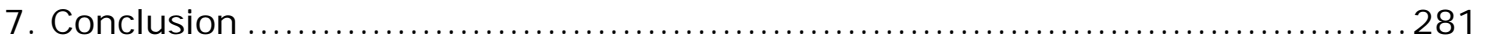

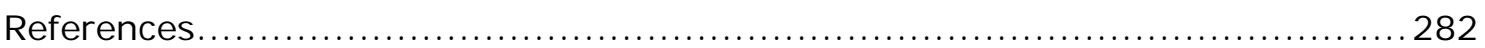

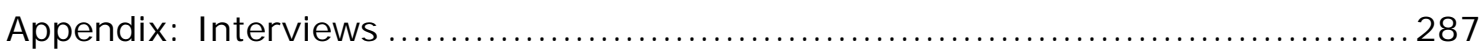




\section{I ntroduction}

It's important to record our history of the struggle - if we don't do it, nobody else will and therefore we will be written out of history. (Anon., 21 December 1993. Fairlea Vigil Diaries. Held in the personal archives of Catherine Gow)

Through an exploration of the role that feminist activism has played in documenting, highlighting and challenging carceral violence, this paper argues that the activist archive constitutes an important site for critical prisons research and action. In line with recent contributions to critical carceral studies that utilise contemporary activist cultural and knowledge productions to intervene in the dominant circulation of carceral logics (Loyd et al. 2012, Berger 2013, Brown 2014, Schept 2015), we draw upon feminist campaign materials from the 1980s and early 1990s in the Australian State of Victoria to (re)construct an anti-carceral activist archive. In particular, we focus on the multi-faceted campaign waged against the punitive segregation of women in maximum-security men's prisons. This case study demonstrates the significance of activist generated paper-trails and critical knowledge formations that not only debunk official rhetoric of the prison's reformative and rehabilitative potential (Russell and Carlton 2013), but also contribute to galvanising coalitional social movements, which we conceive of as anti-carceral feminist coalitions.

Anti-carceral feminism refers to a strand or genealogy of activism dedicated to challenging and resisting practices and rationalities of criminalisation, incarceration and surveillance that are embedded in structural and state violence (Thuma 2015, Carlton 2016). From an anti-carceral feminist perspective, the violence of the prison exists on a continuum, as the prison amplifies and extends mutually constitutive systems of gender/race/class oppression (George and McCulloch 1988, Carlen 1998, Carlton and Segrave 2011). This coalitional feminist tradition is conceived oppositionally to the emergence of what some have termed carceral feminism, which has, through its pursuit of criminalising and punitive solutions to gender and sexual violence, supported and enabled carceral build-up (Bumiller 2008, Bernstein 2010, Davis 2016). The anti-carceral feminist coalitions that we focus on in the Victorian context have been comprised of women's refuges, sex worker collectives, harm reduction organisations, Aboriginal groups, community legal centres and others. Our research demonstrates that activism inside and surrounding women's prisons in Victoria, as in other international locales, functioned "as a lightning rod for crossmovement coalition-building, and as a catalyst for intersectional feminist organising and thinking" (Thuma 2014, p. 28).

The article begins with a discussion of methodological praxis to locate the significance of the activist archive for deepening understandings of anti-carceral feminisms and critical prisons research more broadly. Next, we provide crucial background to our case study by briefly outlining key developments in women's imprisonment and activism in Victoria in the 1980s and early 1990s. We then turn to analyse the collection and dissemination of women's testimonies of segregation in high-security men's prisons and illustrate how thoroughly this administrative violence and the practice of documenting it were equally bound up with women's resistance. The article also considers official and reformist responses to women's segregation, including the possibilities and limitations of the 1991 investigation into conditions for women at Barwon Prison conducted by the Equal Opportunity Commissioner, Moira Rayner. We conclude by highlighting the value of activist knowledge transfer and continued vigilance in the face of historical cycles of reform and punishment. The activist archive, particularly in relation to anti-carceral feminist campaigns, has perhaps previously lacked attention and legitimacy within socio-legal and criminological scholarship focused on critical prisons studies. However, our research demonstrates that it yields a rich base for conceptually mapping historical cycles of carceral violence, reform and expansion through studying how these phenomena have been strategically navigated, exposed and resisted. 


\title{
2. The Activist Archive as Anti-Carceral Feminist Praxis
}

The coalitional movement focused on challenging women's criminalisation and imprisonment in Victoria has been largely self-documented. Various campaigns have generated a prolific corpus of activist and critical carceral knowledge sources, now held in disparate locales: homes, the office of the feminist and prison abolitionist organisation Flat Out, backyard storage sheds, the Public Records Office Victoria, and the Department of J ustice Resource Library. The activist archive, as conceived here, thus exists largely, but not exclusively, outside of institutional sites such as official archival collections. Indeed, feminist historians have long criticised the inadequacy of empirical approaches that fail to consider the effect of gendered power relations on the production, survival, and selection of historical 'evidence' (Allen 1986, Freeman 2005, Harris 2011). Feminist archival research thus necessarily entails excavation and interrogation of both what exists in the archive and what is generally excluded; it also encourages the pursuit and (re)construction of alternative and noninstitutional archives, such as those meticulously constructed, collected and maintained through long-term campaign work.

By using documentary and oral accounts of a decades-long, local anti-carceral feminist movement, as researchers we confront not only the activist labour involved in the production of the archive, but also the gendered labour it fundamentally entails (Meiners and Shaylor 2013). A co-founder of the abolitionist collective Women Against Prison, Amanda George (1993b), who holds an extensive collection of personal archival materials from her long involvement in grassroots organising and legal advocacy around women's imprisonment, described the importance of remaining “vigilant in documenting what we've done even though we're so busy doing it". Her reflections provide a sense of the magnitude and diversity of the work undertaken in the service of campaigns and movement-building:

\begin{abstract}
Labour resources are vital for the volumes of paper, reports, overseas goss[ip], for the ability to keep consistently monitoring, responding and advocating. In the late $80 \mathrm{~s}$ and $90 \mathrm{~s}$ much of this paid work was done in community legal centres. We did this working with women and men in prison and participating in community education and policy work in the Federation of Community Legal Centres Corrections Working Group. The issues we took up came from the concerns of prisoners or areas that we felt were important. Although usually only three people were doing this work it sustained prolific levels of collecting, analyzing, writing, media work, public speaking, and distributing information on women and prison, privatisation, home detention, who is in prison and why they are there, health issues, fines, freedom of information, strip searches, children resident in prison. (George 1993b)
\end{abstract}

Accordingly, the activist archive we access is made up of protest journals and photograph collections, submissions to government and oversight bodies, personal writings and reflections, theatre scripts, personal correspondence with officials and imprisoned women, published papers, conference proceedings, press clippings, public education kits, flyers and other ephemera, as well as official inquiries. As archival materials, they enable analysis of the challenges anti-carceral feminists faced and the strategies they used within and against the system to disrupt the authority and legitimacy of the prison; pre-empt official responses and plans; and pressure for short-term and long-term policy reforms-not only in corrections, but in other areas of social policy, such as public housing and welfare provision (George and McCulloch 1988, Carlton and Russell 2015).

The activist archive contributes to addressing the historical marginalisation of both women's contributions to movements against imprisonment (e.g., Mathiesen 1974) and the relevance of feminism for understanding questions of carceral power and resistance both inside and outside (and often across) prison walls (Law 2009, Faith 2011, Thuma 2014). By drawing upon activist sources and paper trails, what political theorists Maddison and Scalmer (2006) refer to as "activist wisdom", alternative accounts of carceral regimes can be constructed and used to inform critical prisons research and action. Activist wisdom is practical knowledge generated through 
activist experience, experiments and adaptation. It is made up of thoughts, ideas, skills and strategies that drive social movements and is often specific to a local context, though it can be transmuted across regions and borders (Maddison and Scalmer 2006). In particular, our research mobilises activist knowledge as a way to confront the shield of words adopted by criminal justice agencies to soften, reconstruct and ultimately expand gendered practices of containment (Christie 1981, p. 13, Braz 2006). As another co-founder of Women Against Prison, Jude McCulloch, explained, campaigners sought to limit carceral power through documentation and exposure:

We did our best to get alternative sources, to create a paper trail [and] to hold people to account in a context where there [was] massive impunity and [we] hoped that in some ways that served as a restraining factor on power. (J. McCulloch interview, 12 August 2016)

Although archiving is a practice of history (and of assembling and constructing historical narratives), it is also a gesture towards futurity: "Archives are messages to the future. What is deposited and cared for in archives represents a best guess about what (...) will be significant for researchers, society, or individual communities" (Buchanan 2011, p. 41). Research projects that utilise the activist archive are ultimately dependent on the historical documentation and contemporary collection of past campaign ephemera, but also their accessibility to researchers. Occupying the dual spaces of researchers and activists within a contemporary and local decarceration movement has enabled our access to the activist archive to a significant extent, through personal and political connections built over many years. Moreover, our archival research has been shaped and enhanced by other modes of investigation, such as in-depth interviews with key informants. Through conducting interviews and small focus groups, we have discovered and accessed personal archives such as photographs that would not have otherwise been traced. ${ }^{1}$ The assemblage of interview transcriptions and archival sources are read together to shed light on gaps in each form of text and provide new dimensions of historical analysis, such as oral reflections on the past and what has unfolded since that are not often captured in historical documents.

The archival materials subject to analysis comprise forms of "subjugated knowledge" (Foucault 1980 cited in Morgan 1999, p. 329). Imprisoned women's actions and testimonies form the basis of the activist archive and anti-carceral feminist campaign work more broadly. As both feminised and carceral subjects, imprisoned women are generally discredited and dismissed as "biased", "subjective" and "emotive". As Carlton (2007) argues, prisoner accounts rest at the bottom of Becker's (1967, p. 241) "hierarchies of credibility", whereby those with the most power, such as prison authorities and government officials, "have the power to define how things really are", or more simply, what counts as "truth". However, as this case study illustrates, the authoritative status of officials as "primary definers" is always "being resisted or contested by subordinate groups" (Hogg and Brown 1998, p. 19). The testimonies captured in the activist archive were historically mobilised in various legal and public spheres in attempts to achieve multiple social and institutional outcomes, of which most immediately, perhaps, is to end the routine administrative practice of segregating women in high-security men's prisons. But more fundamentally, these accounts were amplified in order to weaken carceral power: to support the agency and survival of imprisoned women, decrease official secrecy and impunity, and build greater public awareness of campaigns against carceral violence. These latter goals remain fundamental to the activist archive, as George (1993a) argues:

\footnotetext{
1 This paper arises from a research project undertaken by the authors that involves extensive archival research, in-depth interviews and focus groups. To date, we have conducted fifteen interviews and two focus groups with key informants, including activists, one former Director of Prisons and the former Equal Opportunity Commissioner Moira Rayner (see Carlton and Russell 2015, Carlton 2016).
} 
The greatest contribution all of us can make to the survival of women who are and who have been in prison, is to become informed about who it is that is sent to prison, what goes on in prison and then to speak out loudly against the myths and lies that surround prison. The greatest prison wall is community and individual ignorance.

As an effort to "speak truth to power" (Scraton 2007), the perspectives and experiences of imprisoned women are captured in the historical record by virtue of their own and others' activism.

\section{Women's I mprisonment and Activism in 1980s Victoria, Australia}

In the early 1980s, a small group of women named the Fairlea Research Group (FRG), compiled a report on women's prison conditions and submitted it to the Victorian Equal Opportunity Board. The report argued that women imprisoned at Fairlea-the only prison for women in Victoria at the time-were experiencing systemic discrimination due to their relatively small numbers in the prison system overall (making up roughly $3.5 \%$ of the total imprisoned population) and the "absence of a policy on prisons for women in Victoria" (Hancock 1982, p. 1). FRG members had covertly gathered evidence from imprisoned women to document the pains of their dormitory style accommodation, punitive classification and discipline procedures, and inadequate medical and health care (Hancock 1982).

Shortly after, in 1982, women in the remand section of Fairlea women's prison deliberately lit a fire to protest the repressive conditions that were by then well documented in the FRG report. Three women died and two escaped (Bolt 1982, The Canberra Times 1982). The fire reduced Fairlea's capacity by half and marked the beginning of the administrative practice of segregating women in men's high-security prisons that would persist into the early 1990s, well beyond the completion of Fairlea's post-fire renovation in 1985. In what activists identified as a retributive move, imprisoned women were first transferred to B Annexe in 1982, an archaic bluestone division of the maximum-security men's prison, Pentridge. Later, as imprisoned women's resistance continued sporadically inside Fairlea in the form of hunger strikes, rooftop riots, peaceful sit-ins, legal complaints and creative theatre performances, women were transferred to other sections of Pentridge, namely the Jika Jika High-Security Unit and G Division (see Table 1). In early 1988, a small minimum-security women's prison was opened 130 kilometres to the north of Melbourne. Tarrengower Prison was promoted by the Office of Corrections as a progressive development and a way "to move the female prisoners out of B Annexe and K Division [Jika Jika]" (from an internal memo produced by the Office of Corrections 1986 - Proposed Female Minimum Security Prison- held in the personal archive of Amanda George), whereas feminist campaigners argued that this additional women's prison was an unnecessary expansion and that its rural location was inaccessible to women's families (Leon 1986, Women Against Prison 1986b, J. McCulloch 1986, unpublished memo - Re: Proposed Female Minimum Security Prison-, held in the personal archive of Trish Luker). ${ }^{2}$

\footnotetext{
${ }^{2}$ Former Director of Prisons John Griffin agreed that, upon reflection, the geographical inaccessibility of the prison caused familial break down and separation from children, rather than facilitating greater access (J. Griffin interview 2015).
} 


\section{TABLE 1}

\begin{tabular}{|l|c|c|c|c|c|c|}
\hline Year & $\begin{array}{l}\text { Pentridge } \\
\text { B Annexe }\end{array}$ & Fairlea & $\begin{array}{l}\text { Pentridge: } \\
\text { Jika Jika } \\
\text { \& G } \\
\text { division }\end{array}$ & Tarrengower & Barwon & Total \\
\hline $\mathbf{1 9 8 2}$ & 33 & 21 & - & - & - & 54 \\
\hline $\mathbf{1 9 8 3}$ & 33 & 21 & - & - & - & 54 \\
\hline $\mathbf{1 9 8 4}$ & 42 & 31 & - & - & - & 61 \\
\hline $\mathbf{1 9 8 5}$ & 40 & 21 & - & - & - & 61 \\
\hline $\mathbf{1 9 8 6}$ & 41 & 44 & 3 & - & - & 88 \\
\hline $\mathbf{1 9 8 7}$ & 41 & 58 & 6 & - & - & 94 \\
\hline $\mathbf{1 9 8 8}$ & - & 87 & 12 & 24 & - & 123 \\
\hline $\mathbf{1 9 8 9}$ & 1 & 86 & 18 & 23 & - & 128 \\
\hline $\mathbf{1 9 9 0}$ & 1 & 79 & 12 & 27 & 6 & 125 \\
\hline $\mathbf{1 9 9 1}$ & 2 & 56 & 5 & 25 & 22 & 110 \\
\hline $\mathbf{1 9 9 2}$ & - & 60 & 11 & 23 & 20 & 114 \\
\hline $\mathbf{1 9 9 3}$ & - & 68 & & 24 & 23 & 115 \\
\hline
\end{tabular}

Table 1. Numbers of women imprisoned in Victoria by institution, 1982-

1993. ${ }^{3}$

Source: Australian Institute of Criminology (1983-1994). ${ }^{4}$

In the mid-1980s, the formation of Women Against Prison continued FRG's work collecting and amplifying imprisoned women's concerns and began building a coalitional movement challenging women's criminalisation and imprisonment more broadly through a combination of tactics and strategies. Campaigns were layered to include public education; systemic advocacy and lobbying; legal tools; and mass mobilisations and direct actions undertaken both within Fairlea women's prison and at its gates (Carlton and Russell 2015, Carlton 2016). In particular, outside activists collaborated with imprisoned women to protest their brutalising conditions in segregation in Pentridge. In 1990, this issue became exigent when the Office of Corrections opened a women's unit in Barwon Prison, a new maximum-security facility designated for men in close proximity to the small township of Lara in Victoria, Australia. This move-in combination with growing pressure from imprisoned and nonimprisoned activists working in concert-soon prompted a formal investigation, led by Commissioner Rayner, into discriminatory conditions for women in Barwon.

\section{Resisting and Documenting Carceral Violence from Within}

The administrative and disciplinary use of high-security segregation for women and men during this period in Australia was generally subject to limited transparency or accountability. However, it was strongly contested by imprisoned and non-imprisoned activists and legal advocates. ${ }^{5}$ Women's first-hand accounts of segregation are powerful expressions of their resistance and survival in the face of incredible violence. They also highlight the deeply sexual and gendered nature of segregation practices in Victoria. The willingness of imprisoned women to make collective and individual complaints provided vital grounds and evidence for activists and community lawyers seeking to publicly expose and redress women's brutal treatment in the prison system and particularly conditions in men's prisons. Without the risks and testimonies of imprisoned women, it is likely that campaigns focused on women's imprisonment would not have taken shape as a coalitional movement. Campaigns fundamentally relied upon "inside-out" (Faith 2000) cooperation and collaborations between

\footnotetext{
${ }^{3}$ As these are census figures collected on 30 June each year, it is important to note that they do not accurately capture the flow-through numbers of women cycling in and out of various prisons over the course of one year.

${ }^{4}$ Figures sourced from a series of reports on Australian prisoners based on the results of the National Prison Census on 30 June, 1982-1993. See Australian Institute of Criminology 1982-1993.

5 In particular, the use of segregation and its human costs attracted public and official scrutiny following the deaths of seven men in a deliberately-lit protest fire in Jika Jika in 1987 (Carlton 2007).
} 
activists and legal advocates, imprisoned women and sympathetic workers within the system, such as nurses, educators and Somebody's Daughter Theatre Group, as we discuss below.

As outlined above, the retributive transfers of women to three different divisions in Pentridge (B Annexe, Jika Jika and G Division) and the Banksia Unit of Barwon Prison during the period 1982-1993 formed a central grievance and focus of anti-carceral feminist activism (see Carlton 2016). There were two key strategies driving the campaign to keep women out of men's prisons. First, anti-discrimination complaints were used as a lobbying platform and legal manoeuvre to pressure the government to cease transferring women to Pentridge and Barwon prisons and to attempt to provide imprisoned women with a form of redress (S. Burchfield interview 2016). Second, and most important for this analysis, Commissioner Rayner's investigation was used by activists-in combination with other tactics-to challenge official impunity and create public awareness of the brutal treatment of women in prison. The events, legal manoeuvring and negotiations between campaigners, Rayner and the state government between the years 1990 and 1993 are complex and multifaceted. The aim of this article is not merely to summarise these events or to evaluate the extent to which reforms were implemented. Rather, we seek to explore how the activist archive was constructed, mobilised and disseminated to expose and challenge carceral violence within and across prison walls.

Imprisoned women's ongoing resistance and increasingly organised forms of protest during the 1980s were met with retributive brutality and neglectful treatment. In the words of Rikki Dewan (cited in Somebody's Daughter Theatre Group 1994, p. 9):

I have had the experience of doing hard time in men's prisons. First - two years in B Annexe in Pentridge Prison, and then the notorious J ika J ika for 9 and a half months, all because I protested about the disgusting conditions and the brutal attacks on women prisoners by male officers. From then on I was branded a 'political prisoner' which means you do all your time hard. 6

Here Dewan describes how attempts to publicise complaints and pursue legal redress placed imprisoned women at grave risk of retributive punishment (see also S. Cook interview 2015). This is what made women's imprisonment political in her terms. A newspaper clipping of a report in The Age describes how in B Annexe, cell "grills are shut at night, after items were hurled at staff during a riot, so the women smash windows for ventilation" (Munday 1985, p.19). Later, in a formal complaint to the Equal Opportunity Commission (EOCV), another imprisoned woman stated that when "in Pentridge, we were locked down most of the time because it's a bloke's jail and we were women. There [was] also constant verbal abuse and sexual harassment" $\left(\mathrm{MB}^{7} 1993\right.$ unpublished, Affidavit in support of application for interim orders pursuant to Section 45A (1) of the Equal Opportunity Act 1984, held in the personal archive of Amanda George).

The Victorian Office of Corrections (OOC) denied campaign claims that segregation was a political response to women's persistence in championing their rights. Instead, women's constructed unruliness in Fairlea Prison was represented as a threat to prison safety and used as a justification for transferring them to men's prisons "for management reasons" (Talbot 1989a, J. Griffin interview 2015). As The Herald reported, "the women were moved to the maximum security area of Pentridge [G Division] while officials "worked out what to do with the troublemakers'" (Talbot 1989b). Official justifications based on the primary imperative of "good order and

\footnotetext{
${ }^{6} \mathrm{Jika} J$ ika, often referred to as an "electronic zoo", was designed as a sensory deprivation prison, consisting of six off-the-ground concrete tunnels with tiny cells, 24-hour air-conditioning and the only exercise areas were in concrete cages (see Gow 1994).

${ }^{7}$ These quotes are taken from unpublished handwritten prisoner complaints about conditions in the men's Pentridge and Barwon prisons. They are not publicly available and held in the personal archives of Amanda George. In order to protect women's identities we have referenced initials rather than listing their full names.
} 
security" and discourses of prisoner "dangerousness" or pathology are typical when questions are raised regarding less than humane and harmful conditions in segregation (Carlton 2007, Scraton 2007, Scraton and Moore 2014). Elsewhere, women's segregation in men's prisons was reported and recalled as simply a pragmatic response to "increasing numbers" and the "bottom line" (Talbot 1989a, Wynne-Hughes interview 2016).

Archival materials associated with women's segregation in Pentridge Prison in the 1980 s are replete with graphic accounts of carceral violence. Much of this violence was routinised and "administrative", including strip searches, and as Dewan (1995) recalled women were often strip searched by male officers. The coercive nature of strip searching practices are most clearly revealed by the consequences of refusal: "[I]f you refused (...) then you were brutally and forcibly held down (...) your clothes were ripped off, your legs kicked open and held, your buttocks parted, then you were turned over" (Dewan 1995, p. 59). Other examples of "excessive" force are recounted, including guard abuses of power and extra-legal assaults:

Nothing is barred. You can get punched, kicked, and batoned repeatedly-and chained like an animal on display in a male prison (...). I have been beaten by male officers on many occasions and had my clothes ripped off. There was one occasion, though, when I was beaten so badly, I became unconscious. The investigating officer at the time took 30 photos of my body from head to toe. I had five stitches in my face, and was hospitalised for days. My charge of assault against these officers was turned down for lack of evidence. (Dewan 1995, p. 60)

The harassment and abuse of imprisoned women was also witnessed by imprisoned men, including a former prisoner from B Annexe, who recalled women screaming in response to officer harassment in the division every night:

One particular night sticks in my mind, it was about 2 am and the screams were getting closer to where my cell door was. It was a woman prisoner getting handled by guards, chased through the men's division, clawing at her friend's cell door. She was screaming for him to help her... all he could do was scream for her and wonder what the screws were doing to her, only hearing her screams and keys jiggling in a scuffle and then silence after all the men had stopped smashing things and banging on their doors (...) I wonder if she is still alive. (Anon., 20 September 1993, Fairlea Vigil Diaries, held in the personal archives of Catherine Gow)

Another prevalent theme in the activist archive is premature death (The Sun 1989, Merkel 1989). Campaign flyers produced by Women Against Prison (n.d.)-“Women Out of Pentridge Now!" and "Close ' $\mathrm{B}$ ' Annexe Now" - argued that the conditions in B Annexe were "the worst in the Victorian prison system" and that the total absence of a drug rehabilitation program combined with solitary confinement conditions was contributing to "attempted suicides in these cells [becoming] weekly occurrences" (see also Women Against Prison 1986a). Indeed, George (1993a; 1999, p. 193) reported that of the seven women who died in prison since 1982, five of these deaths were "suicides in male prisons"-these were the first women to suicide in Victorian prisons. A letter written in the mid-1980s by Women Prisoner's in B Annexe (n.d.) to Women Against Prison activists asked:

How many more have to die before they eventually get us out of here (...). Please do something for us, protest, outside the jail, do anything (...). This place is getting worse and worse (...). We need your help to get us out of this hell hole. ${ }^{8}$

Evidently, women's experiences in Pentridge Prison are relayed in archival materials as sites of "haunting" (Gordon 1997, Saleh-Hanna 2015) and "premature death" (Gilmore 2007):

So many men and women have committed suicide or died in protest in barbaric places like the B Annexe, G Division and Jika Jika. There are too many ghosts and the dead

\footnotetext{
${ }^{8}$ Women Against Prison and the Prisoners' Action Group did protest outside Pentridge Prison following the letter from women prisoners in B Annexe.
} 
haunt the memories of people, like myself and others that did survive the hell of all hells-Jika Jika. (Dewan 1995, p. 60)

Confronting depictions of state violence and their fatal consequences for women transferred to men's prisons were also documented, performed and publicised through mediums of autobiographical writing and prison theatre in a production by Somebody's Daughter Theatre Group, Call My Name. ${ }^{9}$ The play moves between Fairlea and the punishment sections of Pentridge depicting numerous episodes of segregation taking place over a decade. The blurring between character experiences, time and space promotes the feeling that the terror and violence experienced were sustained across places and periods of incarceration. However, the focus of Call My Name is on the notorious transfer of 18 women to Pentridge's G Division, a male psychiatric unit. The women had been branded "trouble-makers" following a sit-in protest inside Fairlea in support of a remanded Aboriginal woman (Flat Out 1988). In the published Call My Name transcript, the glossary states:

Women from Fairlea were taken during the night and, unaware of what was happening or why, were transferred to this unit. The women were kept in this Division for some months and where they were subjected to brutality both physically and emotionally without anyone being aware of where they were held or why. No explanations for this episode were given by the Corrections Department nor any Inquiry undertaken. (Somebody's Daughter Theatre 1994, p. 86)

In a scene from Call My Name, one of the characters, Nat, warns the other women who have also been transferred to Pentridge's G Division:

People disappear here without a trace. This is not fucken [sic] Fairlea (...). We're in with the criminally insane (...). They've sectioned off part of the block for the psychos and thrown us in with them. (Somebody's Daughter Theatre 1994, p. 50)

Call My Name was closely based on imprisoned women's handwritten notes, letters and formal statements compiled during their incarceration in $G$ Division. These unpublished testimonies formed the basis of a collective legal complaint that was never acknowledged by officials (G Division Women 1988, unpublished handwritten legal complaint - Re: Conditions in the Pentridge G Division Signed by 18 Womenheld in the personal archives of Amanda George), yet these harrowing accounts of carceral violence remain in the activist archive. In one document, signed by all 18 women, the ordeal of the G Division transfer was recounted: "[We were] handcuffed and dragged or forced into awaiting prison vans (...) by riot squads, dog squads and special riot squads in orange suits with tear gas, batons, shields in hands and helmets" (G Division Women 11 November 1988, handwritten Legal Complaint - Re: Conditions in the Pentridge 'G' Division Signed by 18 Women-, held in the personal archives of Amanda George). Once in the Pentridge cells every woman was told to strip down and squat on the floor to be searched. Women who refused were forcibly held down by as many as four officers, and then stripped and searched. It was alleged that many of these women were "abused and beaten and thrown around" during this process (G Division Women 1988, unpublished). One woman wrote that she was left in her singlet and pyjama bottoms for four days until she was finally issued with clothing-prison-issue men's uniforms (G Division Women 1988, unpublished). To relieve her stress in conditions of 24-hour lockdown, she cut herself with a piece of glass. She then recounts being charged by the Governor with damaging government property and told it was in her interests to be placed in a wet cell, which "consists of only one canvass mat and a canvass nightie and you sleep on the cement floor with prison officer checking you every 15 minutes" (G Division Women 1988, unpublished). These kinds of testimonies were powerful devices used collaboratively in Call My Name. The play was performed inside Fairlea Prison in 1993 and to the

\footnotetext{
${ }^{9}$ Somebody's Daughter Theatre Company began in Fairlea Women's Prison in 1980. The group facilitated performances by women in prison who came together to "create and perform their own stories, music and art" (Clark 2008, p. 186). The productions were devised by women and performed to invited members of the public in prison. In 1991, these productions were taken out of the prison and performed publicly in a range of forums.
} 
public at Melbourne's CUB Malthouse Theatre the following year. It challenged sanitised official accounts of correctional practices and policies for women through the retelling and depiction of regimes of carceral violence that were otherwise to be excluded from the (official) record.

\section{Reformist Discourses and Official Denial}

In 1989, due to overcrowding at Fairlea and complaints surrounding the treatment of women in G Division in Pentridge, officials flagged that a women's section would be opened at the new Barwon Prison complex. OOC Director-General Peter Harmsworth stated that Barwon, then under construction, "was originally intended to house male prisoners, but the rapid increase in female prisoners is straining current facilities" (Talbot 1989a). Despite claims by Women Against Prison (1989) that the planned move to Barwon "was not the solution" to the extreme violence and stress that women were experiencing in segregation at Pentridge, in October the following year a group of women were moved into the women's-only Banksia Unit of Barwon Prison, prompting one imprisoned woman to write: "I fear the sense of violation and humiliation which accompanies the herding of women into men's gaols" (MS 1993, unpublished document - Complaint to the Equal Opportunity Commissioner: Inquiry into Barwon Prison-, held in the personal archives of Amanda George). The historical legacy of discrimination and gendered segregation within the prison system had until this time escaped a thorough, formal investigation, despite consistent challenges by imprisoned and non-imprisoned activists throughout the 1980s (Hancock 1982, 1986, Federation of Community Legal Centres - hereafter, FCLC- 1990a).

After the negative coverage of archaic and brutal conditions in G Division the Banksia Unit was presented by government officials as a progressive move. A coronial inquest into the death of Karen Watson in G Division on 9 April 1989-who died from an overdose the night before she was due to be released-concluded with reference to the Banksia Unit:

Since Watson's death a new prison at Barwon has been established with a max security Female Management Unit. This is a vast improvement on the 'old' G Division which is also now being renovated and it is hoped that necessary resources will continue to be made available. To do less will result in similar unacceptable conditions as were present in G Division and a greater cost being paid by the community. (Hill 1990, p. 25)

The opening of the Banksia Unit for women effectively converted Barwon into a "coed" prison (FCLC 1990b, p. 1). At the time, George argued that this was a cynical attempt by the $\mathrm{OOC}$ to address requirements embedded in the Equal Opportunity Act 1984 (Vic) related to equal access for women to resources and programs (see Cocorrections, unpublished paper from 1991, held in the personal archive of Amanda George). However, inside Barwon, women faced many of the same pains that they had endured for years in Pentridge: restricted freedom of movement, excessive strip searches and limited access to visits, health services, educational, recreational and industry. The strict segregation of women in a men's institution meant that women lived in a prison within a prison, largely in order to assist with controlling the behaviour of men (Equal Opportunity Commissioner 1992, Office of Corrections 1992). One imprisoned woman described being assaulted by another prisoner while working in the kitchen at Barwon Prison and how she had refused medical appointments to avoid "walking through all the men" (MS 1993, unpublished). She also recounted how she was frequently referred to by staff and prisoners as a "waste of a woman" due to her relationship with another imprisoned woman (MS 1993, unpublished). Another woman reflected, "it is very intimidating-they make personal and embarrassing comments about my personal appearance and sexual practices" (KC 1993, unpublished handwritten document - Complaint to the Equal Opportunity Commissioner: Inquiry into Barwon Prison-, held in the personal archive of Amanda George). Under mounting community pressure, these allegations were subject to formal investigation by Commissioner Rayner in April 1991, who established that 
there was prima facie evidence of both direct and indirect gender discrimination for women held at Barwon Prison (Equal Opportunity Commissioner 1992, Equal Opportunity Commission Victoria 1993). However, the terms of reference for Commissioner Rayner's investigation were limited to Barwon (Equal Opportunity Commissioner 1991), even though advocates attempted to have women's accounts of punitive transfers to B Annexe, Jika Jika and G Division in Pentridge Prison included in the scope.

At the time of women's incarceration in Barwon's Banksia Unit, OOC published a women's correctional policy blueprint, The Agenda for Change (hereafter, AFC) (OOC 1990, Women Prisoners and Offenders Advisory Committee 1991) -a key example of an early attempt at gender-responsive penal programme (Russell and Carlton 2013). George (1993b) characterised the development of the AFC as "a response to the attention generated by women inside jail, and women in the community since 1982". Following its public release in 1991, the AFC was thoroughly challenged by activists and legal advocates and the documentation of these challenges forms an important basis of the activist archive.

The AFC was intended to yield strategic direction for policy development and reform that reflected women's needs and experiences in Victorian prisons ( $S$. Wynne-Hughes interview, 22 November 2016). It rehashed gendered reform discourses that had been circulating in Victoria since at least the 1950s, emphasising "the principle of accommodating women in separate prisons from men" (Harmsworth 1992, p. 3, Russell 1998), despite the (ongoing) practice in Victoria of holding women in prisons intended for men. The draft policy framework noted that this practice had historically contributed to discrimination for women and competition with men for resources and the use of facilities (OOC 1990, p. 19). The AFC further recognised women's "special needs" in relation to "their management, health services, education and training, children's access and involvement in programs"; whereas existing "classification, prison discipline, and management regimes [had been] developed in response to the management of men within a prison environment (...) and in response to the needs of an Anglo-Saxon culture" (OOC 1990, p. 19). As such, the policy blueprint suggested developing appropriate systems of prison management for women.

Following the launch of the AFC, the OOC publicised a women's specific training program for prison staff, new educational programs offered at Fairlea, pilot programs through Community Corrections and the launch of a mother's and baby's special unit (D'Arcy 1992a, 1992b). However, the AFC was frequently met with questions and criticisms because discriminatory practices and sexist harassment continued, such as those documented above by women imprisoned in Barwon. Advocates in community legal centres argued that many of the programs that the OOC launched in the media simply did not exist, as there was poor access to health care for women in Fairlea; no available childcare for women required to complete community-based orders; and an absence of programs (such as safe drug detoxification) to redress the prevalence of self-harm and suicide risk, particularly in Barwon Prison (FCLC 1990a, 1990b, Corrections Working Group 1992). The draft policy framework yielded no clear alternatives to the problems raised and no avenues for imprisoned women to be involved in the decision-making processes that affect their lives. There was a concern that a disproportionate effort had been invested in publicity rather than creating change on the ground (FCLC 1990b, p. 7). As activists working at the Federation of Community Legal Centres in Melbourne argued:

Most recommendations are not specific and say a 'strategy needs development'. This is indicative of an unwillingness to change the practical running of the system and instead focus on policy which as we have shown often bears little relevance to the way the prisons run. Obviously, strategies need to be developed but more urgent is the need to actually do something. (FCLC 1990b, p. 7)

When reporting on her investigation into women's conditions in Barwon Prison, Commissioner Rayner expressed concern that "many good recommendations in the 
[AFC] have not been implemented", such as training for prison staff "in antidiscrimination and human rights law and practice" (Equal Opportunity Commissioner 1992, p. 25). In an interview, Rayner candidly recalled the open sexism and paternalism she witnessed while conducting her investigation. She expressed frustration that women's differential and disadvantageous treatment in Barwon was frequently justified with reference to gendered notions of "difficult" dispositions and sexual vulnerabilities:

When I asked people why they were treating women in a particular way, I would get the usual response that they were unruly and untrustworthy and 'hunted in packs'. And they were doing it to preserve and protect the women from being abused by the men, which raised the obvious question: why were they there anyway? Why were they there in the dangerous situation requiring that they be locked up 24 hours a day? (M. Rayner interview 2015)

In the following years, Rayner (1995) reflected upon the failure of her investigation and the attempt to establish a conciliation process with $\mathrm{OOC}$ to resolve issues of gender discrimination in the prison system and achieve systemic reforms. During this process, the OOC maintained that the AFC had been implemented and frequently referred back to this gender-responsive policy blueprint as evidence of their good intentions (OOC 1992), ultimately avoiding accountability and resisting genuine institutional change. In addition, Rayner was controversially sacked soon after her Barwon Prison investigation in 1993. Her role as Equal Opportunity Commissioner was replaced with a five-person Commission (Rayner 1993a, 1993b). The structural and organisational overhaul of the EOCV effectively reduced its power, preventing any future investigation of discrimination against a class of people, such as women segregated in a men's prison (Rayner 1995).

\section{The Possibilities of Counter-Narratives and Activist Archives}

The resistant counter-narratives we glean from the activist archive, particularly imprisoned women's accounts of carceral violence, profoundly disrupt and undermine discourse generated by the $\mathrm{OOC}$ in the early 1990s that was centred around progress and reform in women's imprisonment. Campaigns spotlighting the issue of gender discrimination within the prison system in Victoria have always sought to expose OOC impunity and to make imprisoned women visible in an institutional and social context in which they were profoundly invisible and largely abandoned (S. Cook et al. focus group 2013, J. McCulloch interview 2016). However, historical analysis of social movements and progressive campaigns show that co-option is a persistent risk and insidious carceral developments cannot always be foreseen (Gottschalk 2006, Bumiller 2008, Murakawa 2014). For example, an FRG member active in the early 1980s, Sandy Cook, acknowledged that the more that they lobbied and campaigned around the need for gender-specific policies for women in prison, the more the system seemed to grow in size. As she stated:

I think part of the problem is [that] the policy response, by and large, adopts the language of a reformist agenda. But what it puts in place is something quite different, under the guise of the newly implemented (...) language of (...) progression. (S. Cook interview 2014)

The outcomes of Commissioner Rayner's investigation into conditions for women in Barwon Prison outlined above illustrates some of the limitations and possibilities of pursuing change through official anti-discrimination legal channels. In an interview, McCulloch reflected that the EOCV process delivered very little systemic change or justice for the women who experienced discrimination whilst segregated in men's prisons. She referred to it as a "farce", while acknowledging that this was in some respects expected by campaigners. From her perspective, there was a necessary element of pragmatism through which these official complaints were pursued:

Putting in an Equal Opportunity complaint was a way of documenting something for history (...) so [that] you can look back on it and say that [it] happened (...). We knew 
it was inadequate. If you got women to be equal in prison, they would only get to be equal to the horrible conditions men had (...). I think later on there probably emerged questions [such as]: if you have a legal strategy does that take over everything else? At the time, I don't remember those conversations happening. All I can remember is that we felt we needed to do all that we could. And that was something we could do. (J. McCulloch interview 2016)

McCulloch's analysis returns us to the importance of the activist archive to ensure that struggles against carceral violence and impunity are not "written out of history". As George (1993b) has argued, women's prison campaigns pressured for "public accountability", but they also "consistently kept alive a discussion of the broad issues that lead to incarceration and the pointlessness of prison as an effective response to crime". Whilst it was waged at an official level, Commissioner Rayner's investigation was fundamentally enabled by activist labour. Rayner confirmed this in an interview, stating that without the organising efforts of activists "who were prepared to go and link hands around Fairlea", it is unlikely that the EOCV would have attempted "to improve the lot of women" because they "never [would] have found out how they were being treated in jail and (...) nothing would have happened. You have to come at it from the grassroots" (M. Rayner interview 2015). It is important to emphasise that these processes were used by campaigners for alternative ends, establishing a considerable paper trail that documents profound neglect, harm and violence associated with gendered segregation practices. The resultant archive establishes OOC policy failures at a time when official rhetoric abounded on the progress and reform associated with the introduction of the AFC. Moreover, legal tools were not used in isolation from other campaign strategies and tactics.

During the course of Rayner's investigation in Barwon, activists had formed a Save Fairlea coalition and established a 24-hour vigil outside Fairlea Prison that lasted for five months, preparing to blockade any attempts to transfer women back to Jika Jika in Pentridge Prison (Gow 1994, Carlton 2016). Whilst 1993 became the last year that women were segregated in men's high-security prisons in Victoria, it also marked the commencement of the first private women's prison experiment in Australia. Ultimately, a range of political, economic and social forces, including this antidiscrimination campaign, drove significant changes in the women's prison system during the 1990s, including the opening of Tarrengower women's prison and the short-lived women's unit in Barwon men's prison; the formalisation of a women's correctional system; and a privatisation programme that accelerated an expansionist trajectory in women's imprisonment in Victoria that has continued to the present day (Hancock 1986, George 1999).

\section{Conclusion}

The preservation and elevation of activist memory is imperative in a local contemporary context where the state is embarking on an unprecedented expansion project at the maximum-security women's prison in Melbourne's Western suburbs (llanbey 2016, p. 5). Moreover, in November 2016 forty young people were transferred to the Grevillea Unit in Barwon Prison as a "wake-up call" following a "riot" in Parkville's youth justice precinct that caused extensive damage to the prison (J ohnston 2016). Echoing (though not replicating) the history that we have traced in this paper, the young men's punitive segregation in Barwon has been challenged by community legal advocates and ruled illegal by the Supreme court (Human Rights Law Centre 2016). Yet, much like the reactive dismissal of Rayner and regressive changes to Equal Opportunity legislation to prevent future collective complaints like that waged by women imprisoned in Barwon in the early 1990s, the government merely re-gazetted Barwon's Grevillea Unit as a youth justice and remand centre (Lee and Preiss 2016), in order to circumvent any legal requirement to reverse the punitive transfer of young people to an adult prison. The ways in which carceral power swiftly reconfigures and consolidates when challenged presents a perennial challenge 
for advocates and activists seeking to prevent institutional violence and excess on a daily basis. As Haley argues:

These continuities [in gendered regimes of punishment and their effects] reflect the urgency of historical scholarship that examines modes of resistance, refusal, and collective organising against carceral sexual and gendered violence. Careful attention to these ideas, acts, movements, and cultures is urgent, especially (...) [given] that expansive critiques have historically been coopted for carceral reform and expansion rather than the necessary goal of abolition. (Kunzel et al. 2016)

Haley's point reinforces the importance of reflecting upon how we mightmethodologically as activists and researchers-examine movement histories and effectively harness anti-carceral feminist critiques in the service of abolition.

The documentary and testimonial practices explored herein were enabled by -and enabling of- a broad-based coalitional movement challenging women's imprisonment and the normalisation of carceral violence. When pursued as discrete actions, antidiscrimination legal frameworks and institutional oversight processes present significant limitations for activists pursuing transformative change such as prison abolition, since they are largely embedded in the knowledge-power structures that maintain carceral systems (Spade 2011, J. McCulloch interview 2016). In Victoria in the 1980s and 1990s, these strategies were pursued by campaigners with a sense of pragmatism. Whilst gravely concerned to ensure the immediate safety of women in prison and improve conditions, activists on both sides of prison walls created paper trails and creatively harnessed various public forums to contest correctional impunity and secrecy.

This paper has emphasised the value of the activist archive to document, expose and challenge carceral violence through a feminist framework. Within the activist archive, a counter-narrative to official teleologies of reform and progress can be traced to instead map subjugated histories of resistance, mutual collaborations across prison walls, and conceptual tools for imagining and building decarceral futures.

\section{References}

Allen, J., 1986. Evidence and silence: feminism and the limits of history. In: C. Pateman and E. Gross, eds., Feminist challenges: Social and political theory. Sydney: Allen \& Unwin.

Australian Institute of Criminology, 1982-1993. Australian Prisoners. Review of Australian Criminological Research [online]. Sydney: Australian Government. Available from:

http://www.aic.gov.au/publications/previous\%20series/npc.html [Accessed 9 J anuary 2018].

Becker, H., 1967. Whose side are we on? Social Problems, 14 (3), 239-247.

Berger, D., 2013. Social movements and mass incarceration: What is to be done? Souls, 15 (1-2), 3-18.

Bernstein, E., 2010. Militarized humanitarianism meets carceral feminism: The politics of sex, rights, and freedom in contemporary antitrafficking campaigns. Signs, 36 (1), 45-71.

Bolt, A., 1982. State warned in 1978 of Fairlea fire hazard. The Age, 8 February.

Braz, R., 2006. Kinder, Gentler, Gender Responsive Cages: Prison Expansion Is Not Prison Reform. Women, Girls, and Criminal J ustice [online],

October/November, 87-91. Available from:

http://www. againstequality.org/wpcontent/uploads/2009/10/gender_responsive_cages.pdf [Accessed 12 J uly 2017]. 
Brown, M., 2014. Visual Criminology and Carceral Studies: Counter-Images in the Carceral Age. Theoretical Criminology [online], 18 (2), 176-197. Available from: http://journals. sagepub.com/doi/abs/10.1177/1362480613508426 [Accessed 21 May 2018].

Buchanan, R., 2011. 'Sweeping up the ashes': The politics of collecting personal papers. Australian Book Review, 337 (December 2011-January 2012), 40-52.

Bumiller, K., 2008. In an Abusive State: How Neoliberalism Appropriated the Feminist Movement against Sexual Violence. Durham, NC: Duke University Press.

Carlen, P., 1998. Sledgehammer: Women's Imprisonment at the Millenium. London: Macmillan.

Carlton, B., 2007. Imprisoning resistance: Life and death in an Australian Supermax. Sydney: Institute of Criminology Press.

Carlton, B., 2016. Penal Reform, Anti-carceral Feminist Campaigns and the Politics of Change in Women's Prisons, Victoria, Australia. Punishment and Society [online], prepublished 24 November. Available from: http://journals. sagepub.com/doi/abs/10.1177/1462474516680205 [Accessed 17 J anuary 2017].

Carlton, B., and Russell, E., 2015. 'A Gender for Change': Cycles of Women's Penal Reform and Reconfigurations of Anti-prison Resistance in Victoria, Australia. Champ pénal/Penal field [online], XII, Abolitionnisme-Abolitionism. Available from: http://journals. openedition.org/champpenal/9103?lang=en [Accessed: 10 January 2018].

Carlton, B., and Segrave, M., 2011. Women's survival post-imprisonment: Connecting imprisonment with pains past and present. Punishment and Society, [online], 13 (5), 551-570. Available from: http://journals. sagepub.com/doi/10.1177/1462474511422174 [Accessed 21 May 2018].

Christie, N., 1981. Limits to Pain. Oxford University Press.

Clark, M., 2008. 'Creativity - The Great Equalizer'. UNESCO E-J ournal, 1 (2), 186193.

Corrections Working Group, 1992. Response to OOC Agenda for Change Review. Melbourne: Corrections Working Group.

D'Arcy, M., 1992a. Implementing the Agenda for Change: A Progress Report. Changing A-Gender. Footscray, Victoria: Women \& I mprisonment Group.

D'Arcy, M., 1992b. Women in Corrections: Working with Women Prisoners - a Training Program. Keypoints, 4 (1), 4-5.

Davis, A.Y., 2016. Freedom is a Constant Struggle: Ferguson, Palestine and the Foundations of a Movement. Chicago, IL: Haymarket Books.

Dewan, R., 1995. In and Out of Prison. In: Women \& Imprisonment Group, ed., Women \& Imprisonment. Melbourne: Fitzroy Legal Service, 59-60.

Equal Opportunity Act 1984 (Vic) [online]. Available from: https://www. legislation.sa.gov.au/LZ/C/A/EQUAL\% 200PPORTUNITY\%20ACT $\%$ 201984/CURRENT/1984.95.UN.PDF [Accessed 10 J anuary 2018].

Equal Opportunity Commission Victoria, 1993. Inquiry into Allegations of Discrimination at Barwon Prison. Melbourne: EOCV.

Equal Opportunity Commissioner, 1991. Inquiry into Sex Discrimination at Barwon Prison. The Age, 11 May. 
Equal Opportunity Commissioner, 1992. Report: Section 41 Inquiry into allegations of discrimination at Barwon Prison. Melbourne: EOC.

Faith, K., 2000. Reflections on Inside/Out Organizing. Social Justice, 27 (3), 158167.

Faith, K., 2011. Unruly Women: The politics of Confinement and Resistance. New York: Seven Stories Press.

Federation of Community Legal Centres, 1990a. Office of Corrections Moves Women Out of Sight to go Out of their Minds. Media release, 1 November. Melbourne.

Federation of Community Legal Centres, 1990b. Response to the OOC Women Prisoners and Offenders Draft Discussion Paper. Melbourne: FCLC.

Flat Out, 1988. Women again being transfered [sic] to Pentridge. Media release. Fitzroy: Flat Out.

Freeman, E., 2005. Time Binds, or, Erotohistoriography. Social Text, 23 (3-4 8485), 57-68.

George, A., 1993a. Commemoration of Women who Have Died In and After Custody. Paper presented at Melbourne Town Hall, 23 March.

George, A., 1993b. Womens Prison Activism in Victoria 1980-1993. Melbourne: Revolting Women Collective.

George, A., 1999. The New Prison Culture: Making Millions from Misery. In: S. Cook and S. Davies, eds. Harsh Punishment: International Experiences of Women's Imprisonment. Boston, MA: Northeastern University Press, 189-210.

George, A., and McCulloch, J., 1988. Women \& Imprisonment in Victoria: A Report. Fitzroy: Fitzroy Legal Service.

Gilmore, R.W., 2007. Golden Gulag: Prisons, Surplus, Crisis and Opposition in Globalizing California. Berkeley, CA: University of California Press.

Gordon, A., 1997. Ghostly Matters: Haunting and the Sociological I magination. Minneapolis, MN: University of Minnesota Press.

Gottschalk, M., 2006. The Prison and the Gallows: the Politics of Mass Incarceration in America. Cambridge University Press.

Gow, C., 1994. No Women in Men's Prisons! No Private Prisons! Australian Feminist Law J ournal, 2, 174-179.

Hancock, L., 1982. Prisoner and Female: the Double Negative. Melbourne: Fairlea Research Group.

Hancock, L., 1986. Economic Pragmatism and the Ideology of Sexism: Prison Policy and Women. Women's Studies International Forum, 9 (1), 101-107.

Harmsworth, P., 1992. Director-General's message. Keypoints, 4 (1), 3.

Harris, V., 2011. Ethics and the Archive: 'an Incessant Movement of Recontextualization.' In: T. Cook, ed. Controlling the Past: Documenting Society and Institutions - Essays in Honor of Helen Willa Samuels. Chicago, IL: Society of American Archivists, 345-362.

Hill, L., 1990. Record of Investigation into Death of Karen Watson. Case no. 1475/89. Melbourne.

Hogg, R., and Brown, D., 1998. Rethinking Law and Order. Sydney: Pluto Press.

Human Rights Law Centre, 2016. Supreme Court finds Government acted unlawfully in Transferring Children to Barwon jail. Media release, 21 December. Melbourne. 
Ilanbey, S., 2016. Twenty Years of 'Better Choices'. Melton \& Moorabool Star Weekly [online], 29 August. Available from: https://issuu.com/starweekly/docs/msw-20160830 [Accessed 10 J anuary 2018].

J ohnston, M., 2016. Barwon Prison to house Young Offenders from Troubled Parkville Youth J ustice Centre. Herald Sun [online], 17 November. Available from: http://www.heraldsun.com.au/news/law-order/barwon-prison-to-houseyoung-offenders-from-troubled-parkville-youth-justice-centre/newsstory/849cd05b18d9c95377fc4747bfb45ee8 [Accessed 10 January 2018].

Kunzel, R., et al., 2016. Histories of Sexuality and the Carceral State - part 3. Notches: (re)marks on the History of Sexuality [online]. Available from: http://notchesblog.com/2016/11/22/histories-of-sexuality-and-the-carceralstate-part-3/?platform=hootsuite [Accessed 17 J anuary 2017].

Law, V., 2009. Resistance behind bars: The struggles of incarcerated women. Oakland, CA: PM Press.

Lee, J., and Preiss, B., 2016. Children to remain at Barwon Prison despite court order to remove them. The Age [online], 29 December. Available from: http://www.theage.com.au/victoria/children-to-remain-at-barwon-prisondespite-court-order-to-remove-them-20161229-gtjhic.html [Accessed 10 J anuary 2018].

Leon, R., 1986. Unnecessary Prison. The Age, 6 November.

Loyd, J., Mitchelson, M., and Burridge, A., 2012. Beyond Walls and Cages: Prisons, Borders, and Global Crisis. Athens, GA: University of Georgia Press.

Maddison, S., and Scalmer, S., 2006. Activist Wisdom: Practical Knowledge and Creative Tension in Social Movements. Sydney: University of New South Wales Press.

Mathiesen, T., 1974. The Politics of Abolition. Oslo: Universitetsforlaget [Oslo University Press].

MB, 1993. Affidavit in support of application for interim orders pursuant to Section 45A (1) of the Equal Opportunity Act 1984, 13 August. Melbourne.

Meiners, E.R., and Shaylor, C., 2013. Resisting Gendered Carceral Landscapes. In: B. Carlton and M. Segrave, eds. Women Exiting Prison: Critical Essays on Gender, Post-Release Support and Survival. Oxon, UK: Routledge, 181-199.

Merkel, A., 1989. Dead jail girl was 'clean' - parents. Sunday Times, 23 April.

Morgan, S., 1999. Prison lives: Critical Issues in Reading Prisoner Autobiography. The Howard J ournal, 38 (3), 328-40.

Munday, J., 1985. A hard option that fails. The Age, 31 May.

Murakawa, N., 2014. The First Civil Right: How Liberals Built Prison America. Oxford University Press.

Office of Corrections, 1990. Women Prisoners and Offenders: Draft Paper for Discussion. Melbourne: Office of Corrections.

Office of Corrections, 1992. Response to the Issues Paper for the EO Commissioner Concerning Allegations of Discriminination at Barwon Prison. Melbourne: Office of Corrections.

Rayner, M., 1993a. A mistake to sack me. Herald Sun, 28 October.

Rayner, M., 1993b. Why the Government has got it wrong. The Age, 28 October.

Rayner, M., 1995. Foreword. In: Women \& Imprisonment Group, ed. Women \& Imprisonment. Fitzroy: Fitzroy Legal Service, iii-v. 
Russell, E., 1998. Fairlea: The History of a Women's Prison in Australia, 1956-96. Melbourne: Australian Scholarly Publishing.

Russell, E., and Carlton, B., 2013. Pathways, race and gender responsive reform: Through an abolitionist lens. Theoretical Criminology [online], 17 (4), 474492. Available from: http://profiles.arts.monash.edu.au/breecarlton/files/2017/02/Russell-and-Carlton.pdf [Accessed 21 May 2018].

Saleh-Hanna, V., 2015. Black Feminist Hauntology: Rememory the Ghosts of Abolition? Champ pénal/Penal field [online], XII. Abolitionnisme-Abolitionism. Available from: https://champpenal.revues.org/9168 [Accessed 17 J anuary 2017].

Schept, J., 2015. Progressive Punishment: Job Loss, Jail Growth, and the Neoliberal Logic of Carceral Expansion. New York University Press.

Scraton, P., 2007. Power, Conflict and Criminalisation. Oxon: Routledge.

Scraton, P., and Moore, L., 2014. The Incarceration of Women: Punishing Women, Breaking Sprits. Basingstoke: Palgrave Macmillan.

Somebody's Daughter Theatre, 1994. Call my Name. Albert Park, Victoria: The Theatre.

Spade, D., 2011. Normal life: Administrative violence, critical trans politics, and the limits of law. Brooklyn, NY: South End Press.

Talbot, L., 1989a. New jail block for women. Herald Sun, 12 April.

Talbot, L., 1989b. Women in Pentridge 'bashed'. Herald Sun, 5 April.

The Canberra Times, 1982. Fairlea fire 'deliberate'. The Canberra Times [online], 9 January, p. 14. Available from:

https://trove.nla.gov.au/newspaper/article/126901233?browse=ndp\% 3Abrow se\% 2Ftitle\% 2FC\%2Ftitle\%2F11\%2F1982\%2F06\%2F09\%2Fpage\% 2F1393851 7\%2Farticle\% 2F126901233 [Accessed 9 January 2018].

The Sun, 1989. Woman dies in prison. The Sun, 10 April, n.p.

Thuma, E., 2014. Against the 'Prison/Psychiatric State': Anti-Violence Feminisms and the Politics of Confinement in the 1970s. Feminist Formations, 26 (2), 2651.

Thuma, E., 2015. Lessons in Self-Defense: Gender Violence, Racial Criminalization, and Anticarceral Feminism. WSQ: Women's Studies Quarterly [online], 43 (3 \& 4), 52-71. Available from: https://muse.jhu.edu/article/594634 [Accessed 21 May 2018].

Women Against Prison, 1986a. How Many More Suicides in 'B' Annexe? Media release, 7 September. Melbourne: Women Against Prison.

Women Against Prison, 1986b. Women and Prison. Media release, 5 May. Melbourne: Women Against Prison.

Women Against Prison, 1989. Women Prisoners Held in Disgusting Medieval Conditions in the Male Psychiatric Division at Pentridge. Media release, 14 April. Melbourne: Women Against Prison.

Women Against Prison, n.d. Women out of Pentridge now! (Flyer). Melbourne: Women Against Prison.

Women Prisoners and Offenders Advisory Committee, 1991. Women Prisoners and Offenders: The Agenda for Change. Melbourne: Women Prisoners and Offenders Advisory Committee. June. 


\section{Appendix: I nterviews}

Burchfield, S. 2016, 16 December. Interviewed by: B. Carlton.

Cook, S. 2015, 11 May. Interviewed by: B. Carlton.

Cook, S., Hancock, L. and Burnup, C. 2013, 11 December. Focus group conducted by: B. Carlton and E. Russell.

Griffin, J. 2015, 20 April. Interviewed by: B. Carlton.

McCulloch, J. 2016, 12 August. Interviewed by: B. Carlton.

Rayner, M. 2015, 14 February. Interviewed by: B. Carlton.

Wynne-Hughes, S. 2016, 22 November. Interviewed by: B. Carlton. 